\title{
Surveillance of Salmonella in Canada (1993 - 1996)
}

\author{
Rasik Khakhria*, David Woodward, Wendy Johnson
}

\begin{abstract}
Abstrak
Selama periode 1993-1996 di Kanada, berdasarkan data laboratorium, telah dilaporkan sebanyak 29.670 kasus infeksi Salmonella. Frekuensi 5 serotip Salmonella yang paling banyak dari sumber manusia adalah : 18,9\% S. Typhimurium, 15,5\% S. Enteritidis, 8,3\% S. Hadar, 7,9\% S. Heidelberg dan 3,2\% S. Thompson. Walaupun urutan dan frekuensi dari serotip tersebut bervariasi dari tahun ke tahun, kelima serotip tersebut merupakan 53,8\% dari semua serotip Salmonella yang diisolasi di Kanada selama 1993-1996. Dari sumber bukan manusia, S. Heidelberg berada di peringkat tertinggi, yaitu 20,1\% (2.343/11.657), diikuti oleh S. Hadar 12,5\% (1.458/11.657). Pada periode tersebut 2 serotipe Salmonella baru telah diidentifikasi oleh LCDC dan diberi nama oleh Institut Pasteur: S. Surrey yang diisolasi dari pasien yang mengadakan perjalanan ke India dan S. Taiping yang diisolasi dari ikan maw kering dari Hongkong. Pada masa kini terjadi peningkatan Salmonellosis pada manusia yang berkaitan dengan binatang piaraan eksotik. Dari tahun 1993 sampai 1995 diperkirakan 3\% - 5\% semua kasus pada manusia dihubungkan dengan paparan terhadap binatang piaraan eksotik, termasuk iguana, kura-kura, Sugar gliders dan landak. Selama periode ini, 188 kejadian luar biasa (KLB) dari berbagai serotip Salmonella telah diteliti. KLB utama disebabkan oleh serotip sebagai berikut: S. Enteritidis, S. Newport, S. Stanley dan S. Typhimurium. Studi tentang hubungan antara KLB dan pejamu binatang dari berbagai serotip dengan penentuan tipe faga menunjukkan bahwa unggas, telur, tunas alfalfa dan produk sapi yang terkontaminasi merupakan sumber infeksi yang umum pada manusia di Kanada. Selama perioda ini dijumpai peningkatan jumlah kasus S. Typhimurium tipe faga (PT) 104, yang biasa dikenal sebagai definite type (DT) 104 (3 kasus pada tahun 1993 menjadi 144 kasus pada tahun 1996). S. Typhimurium DT104 ini dijumpai resisten terhadap satu atau beberapa antibiotika, yaitu ampisilin, kloramfenikol, streptomisin, sulfonamid dan tetrasiklin (tipe R ACSSuT). Satu kejadian dengan 10 kasus S. Typhimurium DT104, tipe R ACSSuT yang terjadi tahun 1995 ternyata bersumber dari daging yang terkontaminasi. Monitor S. Typhimurium DT104 selama tahun 1995 dan 1996 mendapatkan bahwa tipe R ACSSuT bertambah dari 38,3\% pada tahun 1995 menjadi 65\% pada tahun 1996. Surveilans dan identifikasi bahaya dengan menggunakan penanda fenotip memberikan informasi epidemiologik berharga pada insiden, kecenderungan dan faktor risiko yang berkaitan dengan KLB dan kasus klinik yang berhubungan dengan infeksi Salmonella
\end{abstract}

\begin{abstract}
In Canada, during 1993-1996 there were 29,670 laboratory reported cases of Salmonella infections. The frequency of the five most common Salmonella serotypes from human sources were as follows: S. Typhimurium $18.9 \%$, S. Enteritidis $15.5 \%, \mathrm{~S}$. Hadar $8.3 \%$, S. Heidelberg $7.9 \%$ and $\mathrm{S}$. Thompson $3.2 \%$. Although the rank and frequency of these serotypes varied from year to year, these five common serotypes comprised $53.8 \%$ of the total Salmonella serotypes isolated in Canada during 1993-1996. S. Heidelberg ranked first at $20.1 \%$ $(2,343 / 11,657)$ among nonhuman sources, followed by S. Hadar at $12.5 \%(1,458 / 11,657)$. In addition to these, during this period two new Salmonella serotypes identified by $L C D C$ were designated by the Institut Pasteur: S. Surrey isolated from a patient involving travel to India and S. Taiping isolated from dried fish maw from Hong Kong. Recently, there has been an increase of salmonellosis in humans, which has been associated with exotic pets. From 1993 to 1995, an estimated 3\% to 5\% of all human cases were associated with exposure to exotic pets, including iguanas, pet turtles, sugar gliders and hedgehogs. During this period, 188 outbreaks belonging to various Salmonella serotypes were investigated. The major outbreaks belonged to the following serotypes: S. Enteritidis, S. Newport, S. Stanley, and S. Typhimurium. A study of outbreaks and animal-host associations of the various serotypes by phagetyping indicated that contaminated poultry, eggs, alfalfa sprouts and bovine products appeared to be the common sources of human infections in Canada. During this period, there has been an increased number of cases of S. Typhimurium phagetype (PT) 104, commonly known as definite type (DT) 104 (3 in 1993 to 144 in 1996) and they were found to be singularly or multiresistant to the following antibiotics: ampicillin, chloramphenicol, streptomycin, sulphonamide and tetracycline (R-type ACSSUT). One episode of 10 cases of S. Typhimurium DT104, R-type ACSSuT occurred in 1995 was acquired from contaminated meat. Monitoring of S. Typhimurium DT104 during 1995 and 1996 revealed that $R$-type ACSSuT increased from 38.3\% in 1995 to 65\% in 1996. Surveillance and hazard identification using phenotypic markers provide valuable epidemiological information on the incidence, trends and risk factors related to outbreaks and clinical cases associated with Salmonella infections.
\end{abstract}

\footnotetext{
* National Laboratory for Enteric Pathogens, Bureau of Microbiology, Laboratory Centre for Disease Control, Tunney's Pasture, Ottawa, Ontario, Canada
}

\section{INTRODUCTION}

Salmonellosis is one of the most important public health disease problems, affecting more people and animals than any other single disease 1 . In Canada, 
there was a total of 8057 laboratory-confirmed cases of salmonellosis in 1993, 7324 cases in 1994, 7138 cases in 19952, and 7319 cases in 1996. The incidence of human cases of salmonellosis is thought to be many times greater than the number of reported and confirmed cases, even in countries with well-organized surveillance activities ${ }^{1}$. In fact, it is estimated that each year in Canada alone, salmonellosis affects $2.4 \%$ of the total population, an equivalent of 627,200 cases of illness ${ }^{3}$. There can be little disagreement that with the impact of cost on medical care and the loss of productivity, salmonellosis is a very real and underestimated problem ${ }^{1}$.

Surveillance activities of the National Laboratory for Enteric Pathogens involve the collection of national data on salmonellosis from federal, provincial, territorial and public health agencies. Monthly data representing cases of human disease and nonhuman isolates are analysed and disseminated in a timely fashion to health care professionals both nationally and internationally. National data can be used to investigate, identify and control outbreaks, monitor the trends of disease over time, determine risk factors, and detect emerging or re-emerging trends such as multiple drug resistance.

In this study, the prevalence of Salmonella serotypes and phage types is examined.

\section{METHODS AND MATERIALS}

The Salmonella cultures were submitted for identification, serotyping and for phage-typing by various provincial public health laboratories, federal laboratories and veterinary laboratories across Canada.

Serotyping: All serotypes were identified using the typing schemes published by the World Health Organization 4 .

Phage typing: The standard Phage-typing technique described by Anderson and Williams ${ }^{5}$ was employed throughout this investigation. Phages and typing schemes were developed at LCDC (Table 4), or were obtained from the International Collaborating Centre for Enteric Phage typing, Central Public Health Laboratory, Colindale (UK).

\section{RESULTS AND DISCUSSION}

During the four-year period (1993 - 1996), a total of 41,327 Salmonellae isolated from human and nonhuman sources were reported in Canada through a nationwide surveillance system of the National Enteric Reference Centre, LCDC. Of the total, 29,670 Salmonellae were isolated from human sources and the remaining 11,657 were isolated from nonhuman sources. In each of these years, increasing isolations of a few serotypes (Salmonella Typhimurium, $S$. Hadar, $S$. Enteritidis, $S$. Heidelberg) resulted in an increased number of cases in the annual total of reported cases of salmonellosis 2 .

During the four-year period, the 10 most common serotypes accounted for $61.6 \%$ (18.252) of the human isolates and $60.0 \%$ (6993) of the nonhuman isolates (Table 1). Though the yearly rank of frequency of the

Table 1. Ten Most Common Salmonella Serotypes Isolated in Canada From Human \& Non-human Sources (1993-1996)

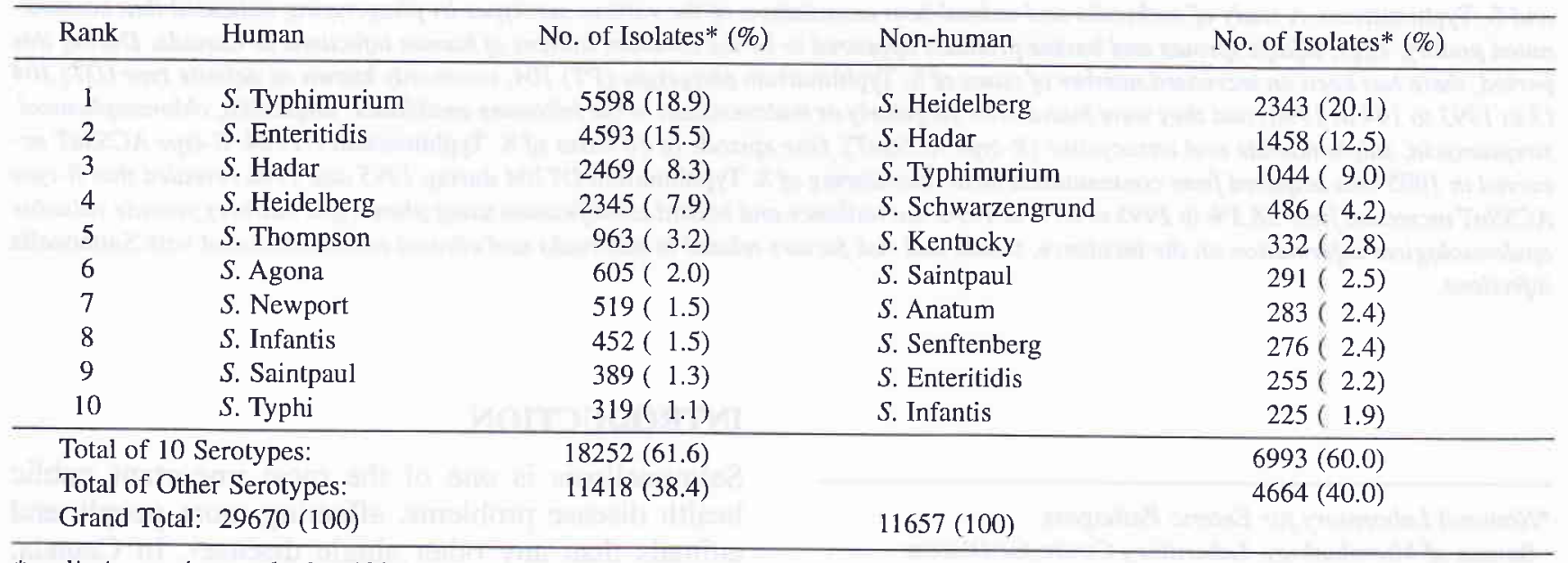

*preliminary data only for 1996 
Table 2. Human Salmonella infections in Canada associated with exotic pets, 1994 to $1996^{11}$

\begin{tabular}{|c|c|c|c|}
\hline Salmonella serotype & $\begin{array}{l}\text { No. of cases } \\
\text { of infection }\end{array}$ & Location* & Epidemiological link \\
\hline S. Poona & 1 & $\mathrm{NF}$ & Associated with pet turtle \\
\hline S. Poona & 1 & $\mathrm{AB}$ & 3-yr old boy; associated with pet iguana \\
\hline$S$. Wassenaar ssp. IV & 1 & SK & Associated with pet iguana \\
\hline S. Wassenaar ssp. IV & 5 & SK & Five cases in one family; associated with pet iguana \\
\hline$S$. Tilene & 5 & $\mathrm{AB}$ & Three cases in one family; associated with pet sugar glider \\
\hline$S$. Tilene & 1 & SK & 4-mo-old baby boy; associated with hedgehog \\
\hline$S$. Tilene & 1 & MB & 2-yr-old baby boy; associated with hedgehog \\
\hline S. Tilene & 2 & $\mathrm{ON}$ & Associated with hedgehogs \\
\hline$S$. Jangwani & 1 & NS & Child visiting a home with baby turtles \\
\hline S. Jangwani & 9 & QU & Associated with turtles \\
\hline S. Montevideo & 1 & MB & Renal transplant recipient; associated with pet iguana \\
\hline S. Marina ssp. IV & 1 & MB & Blood and urine of 11-yr-old boy; associated with pet iguana \\
\hline S. Marina ssp. IV & 2 & MB & Twin baby brothers; associated with iguana in foster home \\
\hline S. Marina ssp. IV & 1 & $\mathrm{AB}$ & Baby boy; associated with iguana in foster home \\
\hline$S$. Braenderup & 1 & $\mathrm{BC}$ & Associated with pet turtle \\
\hline S. Abaetetuba & 2 & $\mathrm{BC}$ & Family has pet iguana \\
\hline$S$. Typhimurium & 1 & $\mathrm{BC}$ & 6-yr-old boy; associated with pet hedgehog \\
\hline$S$. Java & 1 & $\mathrm{BC}$ & Associated with turtle \\
\hline
\end{tabular}

${ }^{*} B C=$ British Columbia, $A B=$ Alberta, $S K=$ Saskatchewan, $M B=$ Manitoba, $O N=$ Ontario, $Q U=$ Quebec, NS $=$ Nova Scotia, $N F=$ Newfoundland

10 most common Salmonella serotypes isolated from human and nonhuman sources varied, $S$. Typhimurium ranked first in human sources where as $S$. Heidelberg ranked first among nonhuman sources. $S$. Hadar's frequency increased rapidly because of its introduction to Canada by importation of turkey breeder stock, which acts as a reservoir. The isolation rate of $S$. Enteritidis from human sources also increased rapidly since $1985^{6}$ and in 1993 , for the first time exceeded that of $S$. Typhimurium ${ }^{2}$. In comparison to $S$. Enteritidis, $S$. Heidelberg was the most common serotype isolated from layer flocks and turkey flocks in Canada, but was less frequently isolated from human sources than $S$. Enteritidis 6 . One of the reasons may be that human hosts, in particular infants, the elderly and the immunocompromised, are more susceptible to $S$. Typhimurium and $S$. Enteritidis than to $S$. Heidelberg7,8.

Recent Salmonella infections in Canada associated with exotic pets are shown in Table 2. At least 37 cases of human salmonellosis with a firmly established epidemiological link to exotic pets were documented in Canada during a 3-year period (1994 1996). These included cases of salmonellosis caused by serotypes $S$. Poona ( 1 case in association with a turtle and 1 case in association with an iguana), $S$. Wassenaar (6 cases in association with iguanas), $S$. Tilene ( 5 cases in association with sugar gliders and
4 cases in association with hedgehogs), $S$. Jangwani (10 cases in association with turtles), $S$. Montevideo ( 1 case in association with an iguana), and $S$. Marina (4 cases in association with iguanas) (Table 2). Among these, two family-related outbreaks occurred, one involving three cases of $S$. Tilene infection associated with pet sugar gliders and a second outbreak involving five cases of $S$. Wassenaar infection associated with a pet iguana (Table 2).

In 1975 Agriculture Canada enacted legislation banning the importation of turtles into Canada; however, imported embryonated turtle eggs may. be a source of continuing human infection in Canada ${ }^{9}$. In the United States, Salmonella serotypes with the same epidemiological link to exotic pets have been observed as causes of disease in humans and have been associated with both morbidity and mortality?

During this period, 23 serotypes not previously reported in Canada were mainly associated with imported food products or travellers and immigrants (Table 3). Among them, two new serotypes, $S$. Surrey and $S$. Taiping were confirmed as a first-time isolation worldwide by the International Collaborating Centre for Salmonella. An important role of surveillance activity is the detection of outbreaks. The early detection of outbreaks provides for the development of effective intervention strategies to halt the spread 
Table 3. First Isolation of Salmonella in Canada (1993-1996)

\begin{tabular}{lll}
\hline Serotype & Formula & Source \\
\hline S. Ahuza & $43: \mathrm{k}: 1,5$ & Human \\
S. Balboa & $48: \mathrm{z} 41:-\mathrm{ssp} \mathrm{V}$ & Human \\
S. Brijbhumi & $11: \mathrm{i}: 1,5$ & Human \\
S. Canastel & $9,12: \mathrm{z} 29: 1,5$ & Tortoise (Imported) \\
S. Caracas & $6,14: \mathrm{g}, \mathrm{m}, \mathrm{s}:-$ & Human \\
S. Elisabethville & $3,10: \mathrm{r}: 1,7$ & Human \\
S. Fluntern & $18: \mathrm{b}: 1,5$ & Iguana (Imported) \\
S. Galiema & $6,7: \mathrm{k}: 1,2$ & Human \\
S. Georgia & $6,7: \mathrm{b}: \mathrm{e}, \mathrm{n}, \mathrm{z} 15$ & Human \\
S. Godesberg & $30: \mathrm{g}, \mathrm{m}:-$ & Halawa (Imported) \\
S. Jangwani & $17: \mathrm{a}: 1,5$ & Human \\
S. Kingabwa & $43: \mathrm{y}: 1,5$ & Human \\
S. Lindern & $6,14: \mathrm{d}: \mathrm{e}, \mathrm{n}, \mathrm{x}$ & Human \\
S. Milwaukee & $43: \mathrm{f}, \mathrm{g}:-$ & Human \\
S. Mpouto & $16: \mathrm{m}, \mathrm{t}:-$ & Human \\
S. Surrey & $21: \mathrm{k}: 1,2,5$ & Human \\
S. Taiping & $13,22: 1, \mathrm{z} 13: \mathrm{e}, \mathrm{n}, \mathrm{z} 15$ & Dried Fish Maw (Imported) \\
S. Tilene & $40: \mathrm{e}, \mathrm{h}: 1,2$ & Human \\
S. Uno & $6,8: \mathrm{z} 29: \mathrm{e}, \mathrm{n}, \mathrm{z} 15$ & Human \\
Salmonella arizonae & $11: \mathrm{v}: 1,5,7 \mathrm{ssp}$ IIIb & Human \\
& $48: \mathrm{lv}: 1,5,7 \mathrm{ssp}$ IIIb & Snake (Imported) \\
& $65: \mathrm{lv}: \mathrm{z}$ spp IIIb & Human \\
& $40: \mathrm{z} 4, \mathrm{z} 23:-\mathrm{ssp}$ IIIa & Snake (Imported) \\
\hline
\end{tabular}

Table 4. Summary of Salmonella Outbreaks Studied By Phage-typing in Canada (1993 TO 1996)

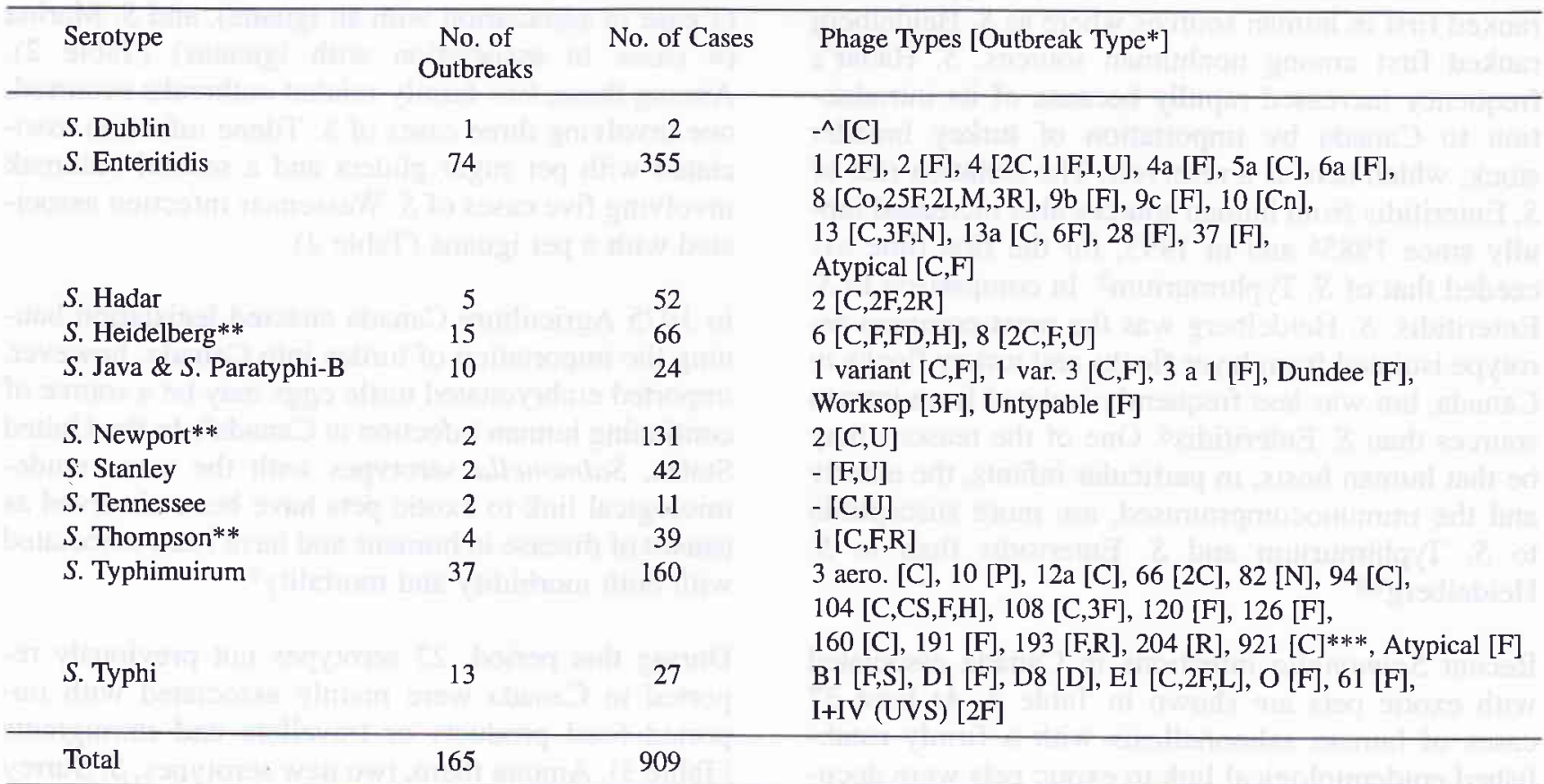

A study of outbreaks and animal-host associations of the various serotypes by phagetyping indicated that contaminated poultry, eggs, alfalfa sprouts and bovine products appeared to be the common sources of human infections in Canada.

$\wedge$ - not typed

* C=community, Cn=contact, Co=convention, $C S=$ catering service, $D=$ daycare, $F=$ family, $F D=$ family dinner, $H=$ hospital $I=$ institution, $L=$ lab-acquired, $M=$ mobile lunch service, $N=$ nursing home, $P=$ party, $R=$ restaurant, $I=$ institution, $L=l a b$-acquired, $M=$ mobile
$S=$ sausage factory staff, $U=$ unknown

** $\quad$ Phagetyping schemes developed for these serotypes at $L C D C$

*** LCDC designation of new type 


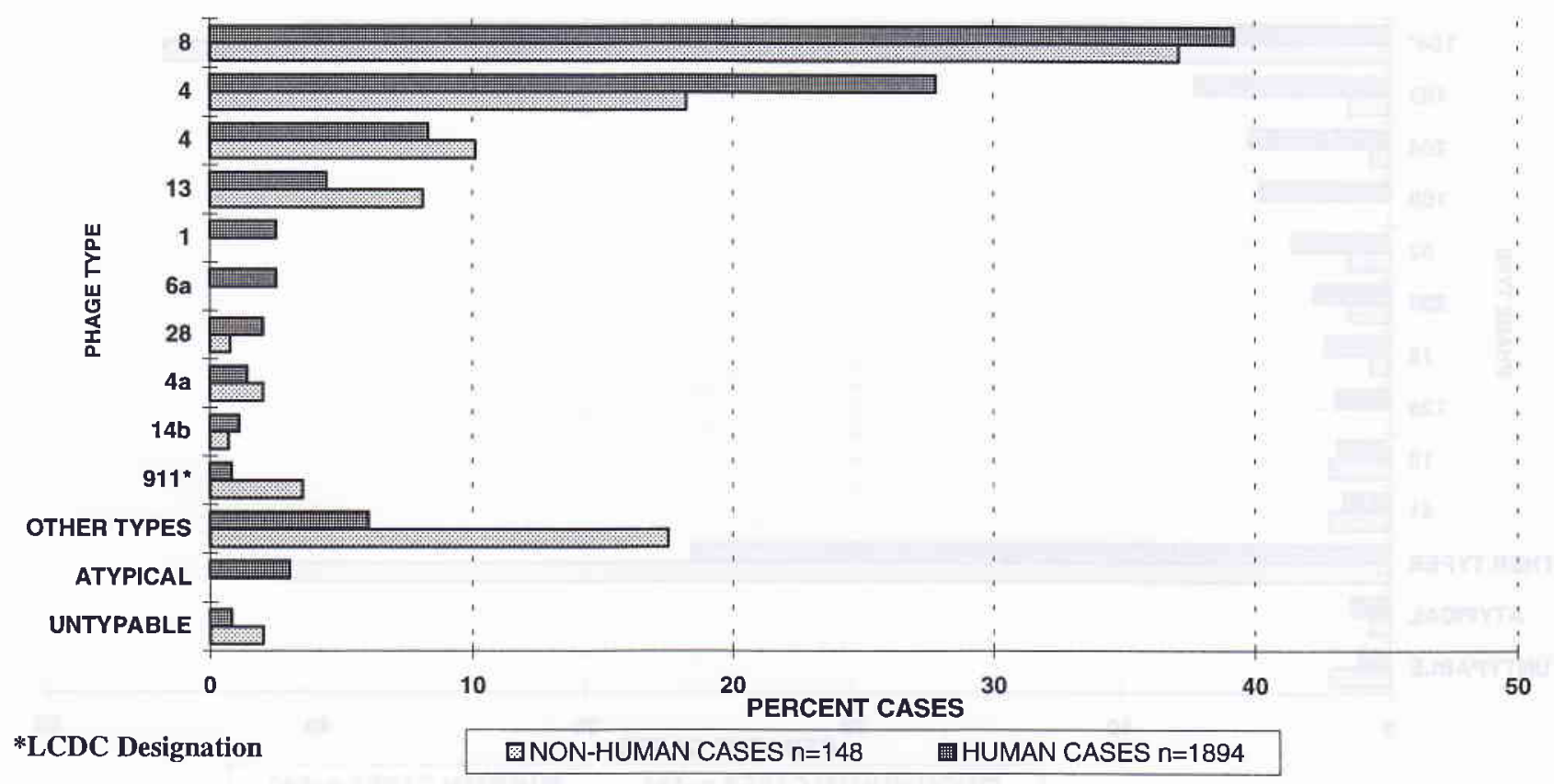

Figure 1. Frequency of the 10 most common S. Enteritidis phage types in Canada, 1993-1996

of the Salmonella within the community. Serotyping and phagetyping of Salmonella have been, and remain, the most useful laboratory tools for the identification of outbreaks. A total of 188 human outbreaks due to various Salmonella serotypes was reported during this four-year period. Of these, 165 Salmonella outbreaks were studied by phage typing (Table 4). The major outbreaks belonged to the following serotypes: $S$. Enteritidis, $S$. Newport, $S$. Stanley and $S$. Typhimurium. The $S$. Enteritidis strains that were isolated from the human outbreaks belonged to 14 different phagetypes. Phage type 8 was the most common among sporadic cases and from these outbreaks (Table 4, Figure 1). Though most of the human $S$. Enteritidis PT4 sporadic and outbreak cases were acquired while travelling abroad 10,1996 surveillance data indicated that $S$. Enteritidis PT4 was established domestically, and the first major outbreak of S. Enteritidis PT4 occurred in Quebec and Ontario linked to the consumption of eggs (unpublished data). A major outbreak of $S$. Newport phage type 2 and $S$. Stanley (same phage pattern) which occurred during 1995 and 1996 were associated with contaminated alfalfa sprouts imported from abroad. The emergence and increased number of cases of $S$.Typhimurium DT104 in Canada have become a recent concern (Figure 2). This phage type replaced DT10 which was the most common in our previous survey ${ }^{6}$. Some of the $S$. Typhimurium DT104 isolates have been resistant to multiple antibiotics, such as ampicillin, chloramphenicol, streptomycin, sulphonamide and tetracycline (R-type ACSSuT). One episode of 10 cases of $S$. Typhimurium DT104, R-type ACSSuT occurred during 1995 was acquired from contaminated meat ${ }^{2}$. Monitoring of $S$. Typhimurium DT104, during 1995 and 1996 revealed that Rtype ACSSuT increased from $38.3 \%$ in 1995 to $65 \%$ in 1996 (Mike Mulvey, personal communication). During this period, $S$. Typhimurium strains belonging to as many as 15 different phage types were isolated from 160 cases in 37 outbreaks (Table 4). $S$. Typhi phage type E1 was common among sporadic and family contact cases. In Canada, the rare phage types, J1, K1, M1 and I+IV were observed among typhoid cases isolated from visitors or immigrants ${ }^{2}$.

This surveillance study provides epidemiological information on the incidence, trends and risk factors related to Salmonella outbreaks and sporadic cases.

\section{Acknowledgements}

We thank the directors and staff of the provincial public health laboratories, federal laboratories, and 


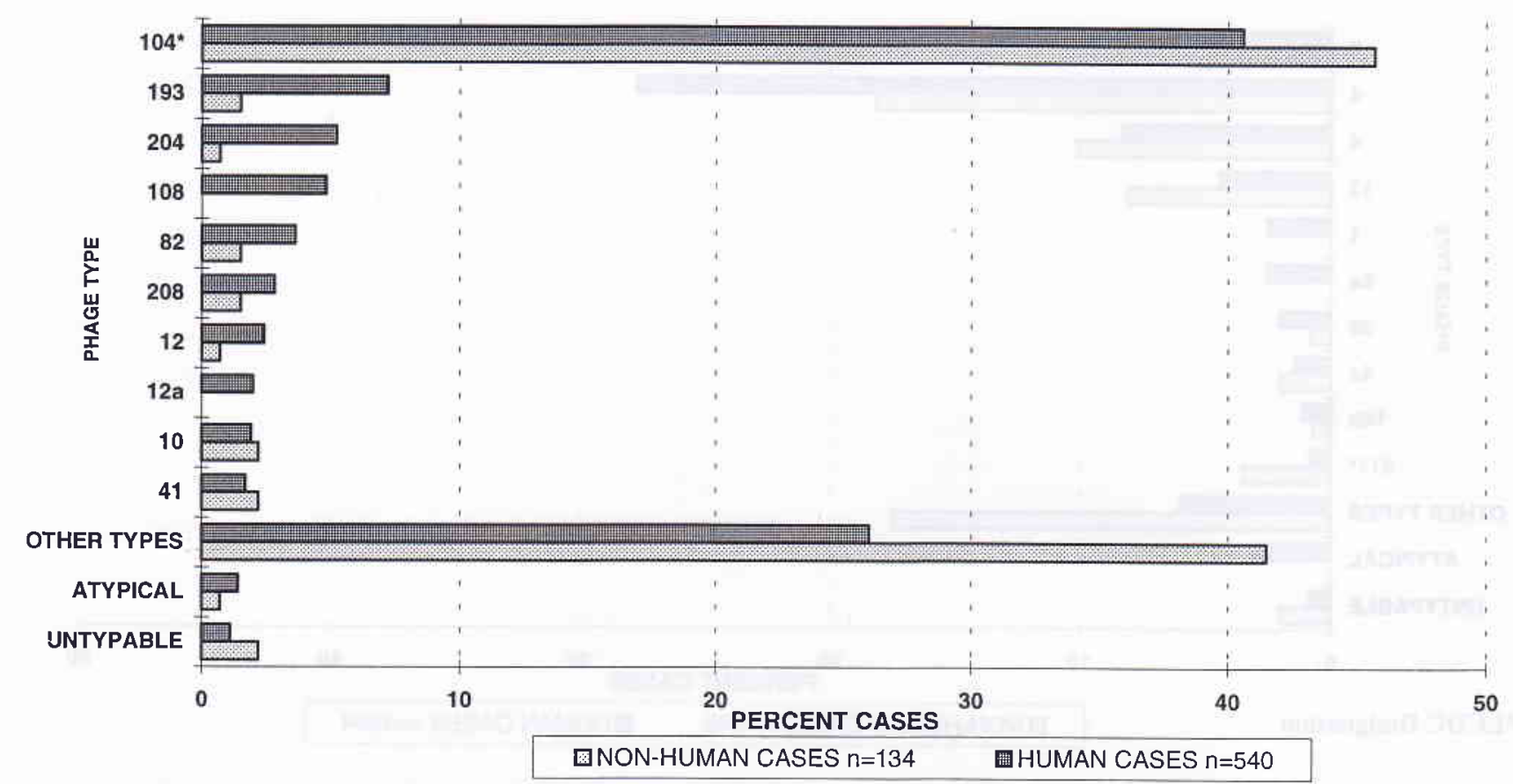

"R-Type ACSSUT increased from 38.3\% in 1995 to $65 \%$ in 1996

Figure 2. Frequency of the 10 most common S. Typhimurium phage types in Canada, 1993-1996

veterinary laboratories for the cultures and data used in this study. Additionally, we thank Gail Christie, Margaret Bell, Rafiq Ahmed, Walter Demczuk, and Darien Duck for the excellent technical assistance that was provided with serotyping and phage typing of the cultures, and thanks is also extended to Marion Bremner for assistance in preparing the manuscript.

\section{REFERENCES}

1. Turnbull PCB. Food poisoning with special reference to Salmonella - its epidemiology, pathogenesis and control. Clin Gastroenterol 1979; 8: 663-713.

2. Khakhria R, Woodward D, Johnson W. Enteric pathogens identified in Canada. Bureau of Microbiology, Laboratory Centre for Disease Control, Health Canada, Ottawa, Ontario, Canada 1993-1995.

3. Todd ECD. Preliminary estimates of costs of foodborne disease in Canada and costs to reduce salmonellosis. J Food Prot 1989; 52: 586-94.

4. Popoff MY, L LeMinor. Antigenic formulas of the Salmonella serovars, 6th ed. WHO Collaborating Centre for Reference and Research on Salmonella. Institut Pasteur Paris, France 1992.
5. Anderson ES, Williams REO. Bacteriophage typing of enteric pathogens and staphylococci and its use in epidemiology. J Clin Pathol 1956; 9: 94-114.

6. Khakhria R, Woodward D, Johnson W, Poppe C. Salmonella isolated from humans, animals and other sources in Canada during the period 1983-1992. Epidemiol Infect 1997; 119: 15-23.

7. Levine WC, Buehler JW, Bean NJT, et al. Epidemiology of nontyphoidal salmonella bacteraemia during human immunodeficiency virus epidemic. J Infect Dis 1991; 164: 81-7.

8. Telzak EE, Budnick LD, Zweig Greenberg MS, et al. A nosocomial outbreak of Salmonella enteritidis infection due to the consumption of raw eggs. N Engl J Med 1990; 323: 394-7.

9. Weinstein JW, Seltzer EG, Nelson RS, et al. Reptile-associated salmonellosis - selected states, 1994-1995. Morbid Mortal Weekly Rep 1995; 44: 347-50.

10. Khakharia R, Duck D, Lior H. Distribution of Salmonella enteritidis phage types in Canada. Epidemiol Infect 1991; 106: 25-32.

11. Woodward D, Khakhria R, Johnson W. Human Salmonellosis Associated with Exotic Pets. J Clin Microb 1997; 35: 278690. 